\title{
Effect of dietary selenium sources in racing pigeons and their effect on antioxidant markers during flying effort
}

\begin{abstract}
The flying effort is considered a critical period for racing pigeons. The increasing stress is associated with weakened immunity, higher susceptibility to diseases and the absence of their expected performance. One way how to prevent these problems is to provide them with minerals supplements based on selenium (Se). Selenium is currently perceived to be a strong antioxidant playing an irreplaceable role in the organism. Selenium forms part of the enzyme glutathione peroxidase (GPx), which participates in eliminating free radicals from the organism. This study investigated the influence of peroral supplementation of organic and inorganic forms of selenium in racing pigeons and their effect on plasma antioxidant markers before and after $350 \mathrm{~km}$ race. The experiment included 30 racing pigeons divided into three equal groups $(\mathrm{n}=10)$. During 30 days before the expected race, the first group (P1) was fed with high naturally organic selenium content of $0.3 \mathrm{mg} \mathrm{Se} / \mathrm{kg}$ of diet while in the control group (C), it was $0.1 \mathrm{mg} \mathrm{Se} / \mathrm{kg}$. The second group (P2) was fed with inorganic form of selenium at a dose of $0.3 \mathrm{mg} \mathrm{Se} / \mathrm{kg}$ of diet in the form of sodium selenite $\left(\mathrm{Na}_{2} \mathrm{SeO}_{3}\right)$ in the same period as in group P1 and control. Blood was taken before supplementation period and after the race to measure antioxidant markers and blood parameters related to muscle metabolism. Plasma selenium concentration and GPx were significantly higher in both supplemented groups after race in comparing to control. Comparing activity of enzymes alanine aminotransferase (ALT), aspartate aminotransferase (ASP), alkaline phosphatase (ALP), creatinine kinase (CK) and lactate dehydrogenase (LDH or LD) at the beginning of the supplementation period didn't show any changes in all experimental groups. The increased activity of all enzymes was observed in all groups after the race. The supplementation with high content of Se in the diet can provide effective antioxidant protection and thus contribute to better performance and rapid recovery of individual birds following their flying efforts.
\end{abstract}

Keywords: racing pigeons, supplementation, antioxidant, selenium, glutathione peroxidase
Volume 2 Issue 5 - 2017

\author{
Frantisek Zigo,' Ladislav Takac,' Martina \\ Zigova, ${ }^{2}$ Jana Takacova' \\ 'University of Veterinary Medicine and Pharmacy, Slovakia \\ ${ }^{2}$ University of Pavol Jozef Safarik in Kosice, Slovakia
}

\begin{abstract}
Correspondence: Frantisek Zigo, University of Veterinary Medicine and Pharmacy, Department of Animal husbandry, Kosice, Komenskeho 73, 040 01, Slovakia, Tel +421-908-689-722, Email frantisek.zigo@uvlf.sk
\end{abstract}

Received: October 30, 2017 | Published: December 14, 2017
Abbreviations: GPx, glutathione peroxidase; Se, selenium; ALT, alanine aminotransferase; CK, creatinine kinase; ALP, alkaline phosphatase; ASP, aspartate aminotransferase; LDH, lactate dehydrogenase

\section{Introduction}

By successfully returning from the race in a winning position, the pigeons demonstrate favourable factors, such as their inherent qualities, health state, stress related to transport and hygiene conditions in their breeding environment. Shortened flying times at competitions and more races per season indicate the higher performance of these birds which is reflected in their health and short periods of regeneration. The increasing stress is associated with weakened immunity, higher susceptibility to diseases and the absence of their expected performance. ${ }^{1}$ One way how to prevent these problems is to provide them with vitamin-minerals supplements which have a strong antioxidant function. In general, the antioxidant system comprises natural fat soluble antioxidants (Eg: vitamin A, a-tocopherols, carotenoids), water soluble antioxidants (Eg: ascorbic acid, uric acid), antioxidant enzymes (glutathione peroxidase GPx and other Se-enzymes, catalase CAT, catalyzer super oxide dismutase SOD), and thiol redox system (glutathione system and thioredoxin system). ${ }^{2,3}$
Selenium is a trace element of importance for animal health. The antioxidative action of Se is determined mainly by its role as an essential component of the active centre of selenoenzymes. ${ }^{4}$ The glutathione peroxidase (GPx) is one of the 25 actually described selenoproteins in which $\mathrm{Se}$ is an essential compound in the active site as selenocystein. ${ }^{5}$ An exercise enhances the metabolism and increases oxygen demand in the locomotive muscles. Consequently, large amounts of reactive oxygen species (ROS) are produced in situ during the effort. The ROS production may exceed the capacity of the protecting scavenger enzyme system causing cellular membrane dysfunction associated with lipids, proteins and nucleic acids oxidations (Figure 1). To protect tissues from oxidative damages, glutathione (c-glutamyl, cysteinyl and glycine), a non-protein thiol source in the cell, reduces hydrogen peroxide and organic peroxides by reaction in which GPx is working as a catalyzer ${ }^{4,6}$ (Figure 1).

In most EU countries the natural Se content in plant proteins, which consists mainly of the selenoamino acids selenomethionine (SeMet) and selenocysteine (SeCys) is only $0.03-0.12 \mathrm{mg} / \mathrm{kg}$ with values more commonly at the lower end of this range. Intake of such feed may result in serious Se deficiency and health problems. For this reason, feedstuffs are routinely supplemented with various Se sources at $0.2-0.3 \mathrm{mg} \mathrm{Se} / \mathrm{kg}$ of dry matter. ${ }^{7}$ The aim of this study was thus to evaluate the effects of peroral supplementation of organic 
and inorganic selenium sources in racing pigeons and their effect on plasma antioxidant markers before and after $350 \mathrm{~km}$ race.

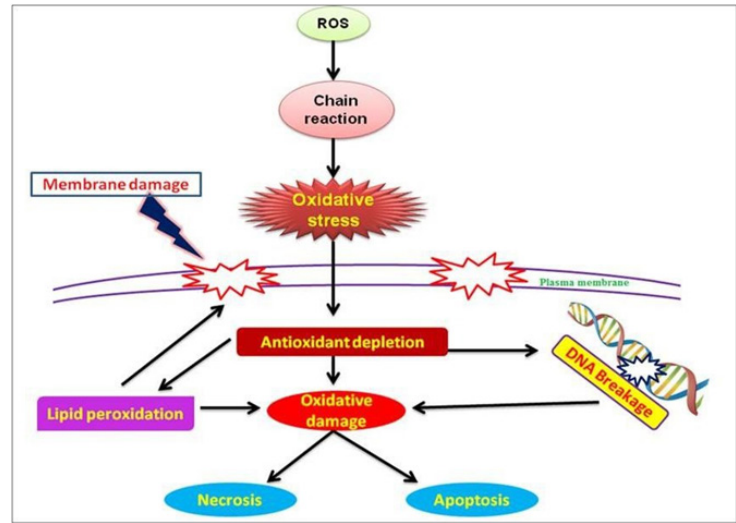

Figure I ROS pathway of cellular destruction.

Reactive oxygen species (ROS) (also known as Free Radicals) are chemically reactive molecules containing oxygen that are formed as product of metabolism.

\section{Material and methods}

\section{Breeding facilities and training pigeons}

Wooden birdhouse (garden-type) measuring $7.5 \mathrm{mx} 2.5 \mathrm{mx} 2 \mathrm{~m}$ with the number of $60 \mathrm{pc}$ of carrier pigeons (Columba livia dom.) divided by mesh into three main sections for pigeons and doves. Each section consisted of a pull-out box with slatted floor and also one feed-pump and a feeder. During the flight season (May to July) pigeons attended a total of 15 races divided by length from the less severe $(120 \mathrm{~km})$ to very challenging distance of $1200 \mathrm{~km}$.

\section{Feeding and selection of pigeons}

From all housed pigeons were selected $30 \mathrm{pc}$ and divided into

Table I Composition of compound feed three equal groups $(n=10)$. During 30 days before the expected race, they were offered a mixture feed enriched of organic and inorganic selenium sources in quantity of $20 \mathrm{~g} \mathrm{pc}$ in the morning and in the evening. The first group (P1) was feed with high naturally organic selenium content of $0.3 \mathrm{mg} \mathrm{Se} / \mathrm{kg}$ of diet while in the control group (C), it was $0.1 \mathrm{mg} \mathrm{Se} / \mathrm{kg}$. The difference in the Se content of diet with high naturally organic selenium content was because of the choice of ingredients which were either high or low in Se. A low Se ingredient was locally produced while another one, high in Se, was imported from Canada. The second group (P2) was feed with inorganic form of selenium $\left(\mathrm{Na}_{2} \mathrm{SeO}_{3}\right)$ after mixing addition at a dose of $0.3 \mathrm{mg} \mathrm{Se} / \mathrm{kg}$ of diet. The formulation and the chemical composition of the two diets are given in Table 1 . The groups P2 and control differed only by the Se content of the diet. In the control group, the Se content was $0.1 \mathrm{mg}$ of $\mathrm{Se} / \mathrm{kg}$ of diet, while in the $\mathrm{P} 2$ group after mixing addition of inorganic selenium $\left(\mathrm{Na}_{2} \mathrm{SeO}_{3}\right)$ it was $0.3 \mathrm{mg}$ of Se/kg dry matter (DM) (Table 1).

\section{Laboratory analysis}

From all three groups blood was taken from vena tarso metatarsica before supplementation period and after the race to measure antioxidant markers and blood parameters related to muscle metabolism. Subsequently, all samples were stored at $-54^{\circ} \mathrm{C}$ until analysis. Concentration of Se in blood plasma was determined using fluorimetric method Rodriquez et al. ${ }^{8}$ Erythrocyte Gpx activity was determined spectrophotometrically using a commercial kit (RandoxRansel, UK) according to Paglia \& Valentine ${ }^{9}$ and expressed as units per gram of haemoglobin. The Se concentration of the samples taken with the feed mixture before and after mixing addition $\mathrm{Na}_{2} \mathrm{SeO}_{3}$ of $0.3 \mathrm{mg} / \mathrm{kg}$ dry matter was determined after the wet mineralization in the microwave module LS 1200 (Nashville, USA), using atomic absorption spectrometry Zeman 4100 (Perkin Elmer, USA) Following the Pechova et al. ${ }^{10}$ The determinations of the enzymatic activities of ALT, AST, ALP, CK and LDH were carried out by diagnostic test kits BIO-LA-TEST (Erba Lachema, Brno, CR) using photoelectric colorimeter as described Duncan et al. ${ }^{11}$

\begin{tabular}{|c|c|c|c|}
\hline Racing mixture diet & Component \% & Naturally organic se enriched racing mixture diet & Component \% \\
\hline Corn (2 Varieties) & 30 & Red Corn & 20 \\
\hline Wheat & 23 & Yellow corn & 10 \\
\hline Barley & 8 & Wheat & 23 \\
\hline Safflower (2 Varieties) & 10 & Safflower Seed & 10 \\
\hline Peas & 6 & Malt Barley & 8 \\
\hline Pea & 6 & Red Milo & 6 \\
\hline Shelled Oats & 5 & White Milo & 6 \\
\hline Dari & 4 & Flax Seed & 5 \\
\hline Millet & 4 & Sterilized Hemp Seed & 5 \\
\hline Rape & 2 & Oats & 5 \\
\hline Vetch & 2 & Canola Seed & 2 \\
\hline $\mathrm{Se}(\mathrm{Mg} / \mathrm{Kg} \mathrm{DM})$ & 93 & $\mathrm{Se}(\mu \mathrm{g} / \mathrm{kg} \mathrm{DM})$ & 306 \\
\hline $\mathrm{Se}^{*}(\mathrm{Mg} / \mathrm{Kg} \mathrm{DM})$ & 318 & - & - \\
\hline
\end{tabular}

Se* - Selenium content after mixing addition $\mathrm{Na} 2 \mathrm{SeO} 3$ of $0.3 \mathrm{mg} / \mathrm{kg}$ DM. 


\section{Statistical analysis}

Tukey's post tests were used to compare all three groups before and after race and significant effect of peroral supplementation was indicated by ANOVA. The values of Se and all monitored enzymes were processed statistically by a non-paired T-test from each group before and after race. Values in tables are means (M) and standard deviation (SD), and $\mathrm{P}<0.05$ was considered as statistically significant.

\section{Results and discussion}

All tissues have the oxidation system protecting pigeons from damaging by biologically relevant molecules, free radicals, and hydrogen peroxide elimination. This involved the protection of antioxidants, which are able to deactivate the charged particle free radical, and discarded them rather than cause the next chain destruction. Among the most effective antioxidants but often deficient in compound feed can be included selenium compounds. ${ }^{1,4} \mathrm{Se}$

Table 2 Selenium levels and enzymatic activity before and after $300 \mathrm{~km}$ race deficiency is a global problem related to an increased susceptibility to various diseases of animals and humans and decreased productive and reproductive performance of farm animals. ${ }^{12}$

Metabolism of Se sources depends on the chemical form of $\mathrm{Se}$ in the diet, and some forms are better for some actions (Eg: cancer reduction) than other forms. Food may contain different amounts and chemical forms of Se. ${ }^{13}$ There are two major sources of Se for pigeons: organic Se, mainly in the form of SeMet, which can be found in any feed ingredient in varying concentrations and inorganic selenium, mainly selenite or selenate, which are widely used for dietary supplementation. ${ }^{14}$ The effect of organic or inorganic Se supplementation into the diets for racing pigeons on the concentration of selenium in blood plasma and enzymatic activity before and after $300 \mathrm{~km}$ race is presented in Table 2. All selenium supplemented groups were significantly increased the plasma Se concentration and the activity of the GPx after race in comparing with control group (Table 2).

\begin{tabular}{|c|c|c|c|c|c|}
\hline \multirow{2}{*}{ Parameter } & \multirow{2}{*}{ Unit } & \multirow{2}{*}{ Period } & PI Group & P2 Group & C Group \\
\hline & & & $M \pm S D$ & $M \pm S D$ & $M \pm S D$ \\
\hline \multirow{2}{*}{$\mathrm{Se}$} & \multirow{2}{*}{$\mu g . \mid-I$} & Before & $62.4 \pm 4.7$ & $64.2 \pm 4.1$ & $60.7 \pm 5.4$ \\
\hline & & After & $110.7 \pm 6.1^{b}$ & $102.2 \pm 7.4^{b}$ & $71.6 \pm 4.4^{a}$ \\
\hline \multirow{2}{*}{ GPx } & \multirow{2}{*}{$\mathrm{IU} / \mathrm{g} \mathrm{Hb}$} & Before & $54.3 \pm 5.7$ & $49.5 \pm 4.8$ & $58.5 \pm 6.2$ \\
\hline & & After & $82.4 \pm 7.8^{b}$ & $79.6 \pm 6.5^{b}$ & $54.1 \pm 5.3^{\mathrm{a}}$ \\
\hline \multirow{2}{*}{ ALP } & \multirow{2}{*}{ IU/L } & Before & $126.4 \pm 10.1$ & $119.3 \pm 12.4$ & $133.6 \pm \mid 4.7$ \\
\hline & & After & $374.2 \pm 28.3$ & $342.4 \pm 27.1$ & $383.2 \pm 31.3$ \\
\hline \multirow{2}{*}{ AST } & \multirow{2}{*}{ IU/L } & Before & $107.0 \pm 9.0$ & $93.7 \pm 8.2$ & $111.5 \pm 10.4$ \\
\hline & & After & $258.0 \pm 24.5$ & $236.6 \pm 19.5$ & $268.3 \pm 27.9$ \\
\hline \multirow{2}{*}{ ALT } & \multirow{2}{*}{ IU/L } & Before & $23.6 \pm 2.8$ & $18.7 \pm 2.1$ & $24.7 \pm 4.2$ \\
\hline & & After & $37.3 \pm 4.8$ & $35.7 \pm 6.2$ & $4 I . I \pm 5 . I$ \\
\hline \multirow{2}{*}{ CK } & \multirow{2}{*}{ IU/L } & Before & $|47.2 \pm 22|$. & $178.3 \pm 37 . \mid$ & $|56.7 \pm 3| .3$ \\
\hline & & After & $405.4 \pm 49.2$ & $447.2 \pm 53.6$ & $471.4 \pm 44.9$ \\
\hline \multirow{2}{*}{ LDH } & \multirow{2}{*}{ IU/L } & Before & $128.7 \pm 10.7$ & $110.8 \pm 11.1$ & $117.5 \pm 9.4$ \\
\hline & & After & $267.3 \pm 30.6$ & $240.6 \pm 32.7$ & $258.9 \pm 28.5$ \\
\hline
\end{tabular}

PI group-pigeons feed with high naturally organic selenium content, P2 group - feed with inorganic form of selenium after mixing addition, $\mathrm{C}$ group - control group feed with low Se content.

${ }^{a, b}$ significance level $p<0.01$ is presented by different superscripts in a row.

Schoenh et al. ${ }^{4}$ have confirmed the increased amount of hydroxide radicals during a 2-hour flight simulation of carrier pigeon. However, the authors reported a faster degradation of the hydroxide radicals and enhanced activity of GPx in the group of pigeons, which has been supplemented with the addition of $195 \mu \mathrm{g} \mathrm{Se} \mathrm{kg}$ feed vs. the pigeons that were fed a normal amount of a mixture of $30 \mathrm{mg} \mathrm{Se} / \mathrm{kg}$ feed. Enzymes of muscle metabolism are characterized by a very wide range of activity, the interpretation of variations of these enzymes is difficult. Nevertheless, these enzymes may be adversely affected by factors such as muscular injury, rupture of organs, nutritional status, physical activity, hemolysis, treatment, and conservation of plasma samples and their levels in blood can increase. Also, these enzymes can be an important diagnostic tool in veterinary medicine. ${ }^{15}$ Table 3 presents the activity of the investigated enzymes during the period of Se supplementation. Comparing the activity of enzymes ALT, ASP, ALT and CK at the beginning of the supplementation period were not recorded. The increased activity of all enzymes has been observed after the race in all study groups (Table 3).

AST activity currently is considered a very sensitive but nonspecific indicator of hepatocellular disease in avian species, and is frequently used with the muscle-specific enzyme CK to differentiate between liver and muscle damage. ${ }^{16}$ In our study were significantly increased CK with AST, ALP and ALT which are good indicators of muscle damage. 
Table 3 Comparison of enzymes muscle metabolism in each group before and after race

\begin{tabular}{|c|c|c|c|c|c|c|c|c|}
\hline \multirow{2}{*}{\multicolumn{2}{|c|}{ Parameter }} & \multirow{3}{*}{$\begin{array}{l}\text { Physiological references } \\
24-104\end{array}$} & \multicolumn{2}{|c|}{ PI group } & \multicolumn{2}{|c|}{ P2 group } & \multicolumn{2}{|c|}{ Control group } \\
\hline & & & \multirow{2}{*}{$\begin{array}{l}\% \\
197\end{array}$} & \multirow{2}{*}{$\begin{array}{l}\mathbf{P} \\
P<0.001\end{array}$} & \multirow{2}{*}{$\begin{array}{l}\% \\
187\end{array}$} & \multirow{2}{*}{$\begin{array}{l}\mathbf{P} \\
P<0.00 I\end{array}$} & \multirow{2}{*}{$\begin{array}{l}\% \\
189\end{array}$} & \multirow{2}{*}{$\begin{array}{l}\mathbf{P} \\
P<0.001\end{array}$} \\
\hline ALP & IU/L & & & & & & & \\
\hline AST & IU/L & $45-123$ & 141 & $P<0.00 I$ & 154 & $P<0.00 I$ & 140 & $P<0.001$ \\
\hline ALT & IU/L & May-45 & 62 & $\mathrm{P}<0.0 \mathrm{I}$ & 98 & $P<0.01$ & 71 & $P<0.01$ \\
\hline CK & IU/L & $110-480$ & 175 & $P<0.00 I$ & $|5|$ & $P<0.00 I$ & 201 & $P<0.001$ \\
\hline LDH & $\mathrm{IU} / \mathrm{L}$ & 30-205 & 108 & $P<0.001$ & 118 & $P<0.00 I$ & 120 & $P<0.001$ \\
\hline
\end{tabular}

P - Significance level, \% - percentage difference between the compared values before and after race.

\section{Conclusion}

The higher Se plasma levels and increased activity of GPx were achieved by oral supplementation of organic and inorganic Se sources after the race in comparison with the control group, which was without the addition. The increased activity is explained by physical muscular effort and leaching of free radicals. The impact of these mineral additions of the enzyme biochemistry values of ALP, AST, ALT, CK and LDH, by their increased activity of the muscle exertion, have not been significant as a factor affecting their activity. Pigeons are birds that are characterized by a high potential of racing fly and are thus submitted to intense oxidative stress. Supplementation based on Se is not only an effective way of antioxidant defense resulting in better performance but also helps with rapid recovery of airworthy burdened individuals.

\section{Acknowledgements}

None.

\section{Conflict of interest}

The author declares no conflict of interest.

\section{References}

1. Vargová V, Zigo F, Chripková $\mathrm{M}$, et al. Influence of peroral supplementation of selenium and vitamin $\mathrm{E}$ on the antioxidant status of racing pigeons. Folia Veterinaria. 2016;60(3):24-28.

2. Arpášová $H$, Mellen $M$, Kačániová $M$, et al. Effects of dietary supplementation of sodium selenite and selenized yeast on selected qualitative parameters of laying hens eggs. Slovak J Anim Sci. 2009;42(1):27-33

3. Ševčikova S, Skřivan M, Dlouha G, et al. The effect of selenium source on the performance and meat quality of broiler chickens. AGRIS. 2006;51(10):449-457.

4. Schoonheere N, Dotreppe O, Pincemail J, et al. Dietary incorporation of feedstuffs naturally high in organic selenium for racing pigeons (Columba livia):effects on plasma antioxidant markers after a standardised simulation of a flying effort. J Anim Physiol Anim Nutr (Berl). 2009;93(3):325-330.
5. Gromer S, Eubel JK, Lee BL, et al. Human selenoproteins at a glance. Cell and Mol Life Sci. 2009;62:2414-2437.

6. Alessio HM. Exercise-induced oxidative stress. Med Sci Sports Exerc. $1993 ; 25(2): 218-224$.

7. Petrovi ̌ V, Kushev J, Nollet L, et al. Effect of dietary supplementation of trace elements on blood chemistry and selected immunological indices depending on the age of broiler chickens. Acta Vet Brno. 2011;80:57-64.

8. Rodriguez EM, Sanz MT, Romero CD. Critical study of fluorometric determination of selenium in urine. Talanta. 2011;41(12):2025-2031.

9. Paglia DE, Valentine WN. Studies on the quantitative and qualitative characterization of erythrocyte glutathione peroxidase. J Lab Clin Med. 1967;70(1):158-169.

10. Pechová A, Pavlata L, Illek J. Blood and tissue selenium determination by hydride generation atomic absorption spectrophotometry. Acta Vet Brno. 2005;74(4):483-490.

11. Duncan JR, Prasse KW, Mahaffey EA. Veterinary laboratory medicine, Clinical Pathology. USA: Iowa State University Press; 1994.

12. Lyons MP, Papazyan TT, Surai PF. Selenium in food chain and animal nutrition: Lessons from nature. Asian-Aust $J$ of Anim Sci. 2007;20(7):1135-1155.

13. Finley JW. Increased intakes of selenium-enriched foods may benefit human health. AGRIS. 2007;87:1620-1629.

14. Surai PF, Karadas F, Pappas AC, et al. Effect of organic selenium in quail diet on its accumulation in tissues and transfer to the progeny. Br Poult Sci. 2006;47(1):65-72.

15. Harr KE. Clinical chemistry of companion avian species:A Review. Vet Clin Pathol. 2006;31(3):140-151.

16. Mohammed A. Blood biochemical profile of young and adult racing pigeons (Columba livia domestica) in Egypt. Middle East J of App Sci. 2014;4(3):528-538. 